\title{
PENGARUH MEKANISME CORPORATE GOVERNANCE DAN MANAJEMEN LABA TERHADAP KINERJA KEUANGAN PERUSAHAAN YANG TERDAFTAR DI INDEKS LQ 45
}

\author{
Fariz Maulana Ghazali ${ }^{\mathrm{a}}$ \\ Andry Irwanto ${ }^{\text {b }}$ \\ ${ }^{a}$ Sekolah Pascasarjana Universitas Airlangga ${ }^{b}$ Fakultas Ekonomi dan Bisnis Universitas Airlangga \\ Email: maulanaghazali.f@yandex.com ${ }^{\text {a }}$ andryirwanto149@gmail.com ${ }^{b}$
}

ARTICLE HISTORY

Received:

5 June 2019

Revised

10 July 2019

Accepted:

24 July 2019

Online available:

10 November 2019

Keywords:

managerial ownership, institutional

ownership, independent commissioner, audit committees, earnings management, financial performance

\section{ABSTRACT}

Introduction: The objective of this research is to examine how to influence of corporate governance and earnings management on financial performance.

Methods: Independent variables in this research are managerial ownership, institutional ownership, independent commissioners, audit committees and earnings management. Dependent variable is financial performance. Earnings management in this research was measured using Modified Jones Models, while financial performance was measured by cash flow return on assets (CFROA). Sampel was conducted on the company that listed at Indeks 45 Indonesia Stock Exchange. The sample period of this research is 2013. Data of this research are analyzed using multiple regression.

Results: The results of the analysis show that managerial ownership, institutional ownership, independent commissioners and audit committees have not influence to financial performance. Earnings management have influence to financial performance.

Conclusion and suggestion: Subsequent research can make comparisons between stock indices on the Indonesia Stock Exchange and the use of different models in determining corporate governance and discretionary accruals and extending the observation period so that there are mechanisms for corporate governance and earnings management with different points of view. 


\section{INTRODUCTION}

Para pelaku pasar modal memerlukan informasi mengenai kinerja perusahaan, yang diantaranya berupa kinerja keuangan perusahaan melalui laporan keuangan yang dipublikasikan untuk mengambil keputusan investasi. Kinerja keuangan yang dilihat melalui laporan keuangan dapat memberikan gambaran yang sebenarnya mengenai keefektifan dan keefisienan perusahaan dalam mengelola aset atau sumber daya yang dimilikinya untuk mencapai sasaran dan tujuan perusahaan.

Laporan keuangan sebagai salah satu sumber informasi yang dihasilkan perusahaan juga tidak terlepas dari proses penyusunannya yang tergantung dari prinsip akuntansi berlaku umum yang digunakan oleh perusahaan. Laporan keuangan yang didalamnya memuat kinerja keuangan perusahaan merupakan hasil dari banyak keputusan individual yang dibuat secara terus menerus oleh manajemen. Kebijakan dan keputusan yang diambil dalam menyusun laporan keuangan akan mempengaruhi penilaian kinerja perusahaan.

Meskipun demikian, sering terjadi kecurangan yang dilakukan oleh pihak tertentu dalam menyusun laporan keuangan dan merugikan para stakeholder perusahaan. Ujiyantho dan Pramuka (2007) menyatakan bahwa terkadang apa yang disampaikan oleh laporan keuangan tidak mencerminkan kondisi sebenarnya, sehingga menimbulkan adanya asimetri informasi yang berdampak pada keputusan investasi yang kurang tepat.

Corporate governance merupakan konsep yang digunakan untuk meningkatkan kinerja perusahaan melalui pengawasan kinerja manajemen dan menjamin akuntabilitas manajemen terhadap stakeholders dengan mendasarkan pada kerangka peraturan. Penerapan corporate governance yang baik oleh perusahaan merupakan salah satu upaya untuk mengurangi adanya asimetri informasi.

Corporate governance membantu terciptanya hubungan yang kondusif dan dapat dipertanggungjawabkan antar elemen di dalam perusahaan yang meliputi dewan komisaris, dewan direksi, komite audit, dan pemegang saham dalam rangka meningkatkan kinerja perusahaan. Dewan komisaris yang didalamnya terdapat komisaris independen yang memiliki tugas untuk memastikan bahwa manajemen telah bekerja dengan benar demi tercapainya tujuan perusahaan melalui strategi yang telah dan akan dilakukan serta menjaga kepentingan para pemegang saham untuk meningkatkan nilai perusahaan. Komite audit memiliki peran yang penting dalam hal memelihara kredibilitas proses penyusunan laporan keuangan, menjaga terciptanya pengawasan perusahaan dan pelaksanaan good corporate governance.

Pengaruh corporate governance terhadap kinerja keuangan telah diteliti oleh Manik (2011), Hanani dan Aryani (2011), Romano etal. (2012), Widayawati (2013), Martsila dan Meiranto (2013), dan Halim (2013), dimana terdapat perbedaan mengenai pengaruh dari variabel corporate governance yang digunakan terutama meliputi variabel

Published by University of Airlangga.

This is an open access article under the CC BY license (https://creativecommons.org/licenses/by-sa/4.0/) 
kepemilikan manajerial, kepemilikan institusional, komisaris independen, dan komite audit terhadap kinerja keuangan.

Kecurangan yang dilakukan oleh pihak tertentu dalam menyusun laporan keuangan dan merugikan para stakeholder perusahaan ini terjadi diantaranya juga karena investor dan pihak eksternal lainnya yang cenderung berfokus pada informasi laba, sehingga memicu disfunctional behaviour oleh pihak manajemen dalam melakukan manajemen laba (earnings management).

Manajemen laba juga merupakan fenomena yang sukar untuk dihindari karena fenomena ini merupakan dampak dari penggunaan dasar akrual dalam menyusun laporan keuangan. Manajemen laba dapat diklasifikasikan menjadi tiga kategori yaitu akuntansi yang curang, manajemen akrual, dan manajemen laba nyata (Gunny, 2005). Manajemen laba terjadi pada saat manajemen menggunakan suatu kebijakan dalam pelaporan keuangan dan penyusunan transaksi untuk mengubah laporan keuangan dengan maksud mempengaruhi persepsi stakeholders mengenai kinerja perusahaan atau mempengaruhi hasil kontraktual yang tergantung pada nilai akuntansi yang dilaporkan (Healy dan Wahlen, 1999).

Penelitian-penelitian terdahulu yang dilakukan Dechow et al. (1995), DeFond \& Jiambalvo (1994), Peasnell, Pope \& Young (2000), Chen et al. (2007), Yang et al. (2008), Alves (2013), Nuryaman (2013), Ardekani, Younesi \& Hashemijoo (2013); Chaibi, Trabelsi \& Omri (2013) dan Halim (2013) melakukan pengukuran manajemen laba menggunakan pendekatan aggregate accruals untuk mengukur adanya tindakan manajemen laba. Pendekatan tersebut berusaha memisahkan total akrual menjadi komponen nondiscretionary accruals (merupakan komponen akrual diluar kebijakan manajemen) dan discretionary accruals (komponen akrual yang berada dalam kebijakan manajemen atau manajer melakukan intervensi dalam proses pelaporan keuangan).

Kinerja perusahaan yang dihitung dengan rasio keuangan, tidak akan dapat dipisahkan dari ukuran perusahaan yang dicerminkan dengan total aset yang dimiliki. Semakin besar aset yang dimiliki perusahaan, memungkinkan kinerja keuangan suatu perusahaan semakin besar pula. Cash Flow Return On Asset (CFROA) merupakan salah satu pengukuran kinerja keuangan perusahaan yang menunjukkan kemampuan aktiva perusahaan untuk menghasilkan laba operasi. CFROA lebih memfokuskan pada pengukuran kinerja perusahaan saat ini dan CFROA tidak terikat dengan harga saham (Cornettt et al., 2006).

Selain variabel yang telah dijelaskan diatas, diperlukan pula sampel perusahaan yang ingin diuji terutama berkaitan dengan emiten pasar modal. Dalam pasar modal terdapat beberapa indeks harga saham sebagai indikator atau cerminan pergerakan harga saham. Indeks merupakan salah satu pedoman bagi investor untuk melakukan investasi di pasar modal, khususnya saham. Salah satunya indeks dalam pasar modal Indonesia adalah indeks LQ45. Indeks ini terdiri dari 45 saham tercatat yang dipilih berdasarkan pertimbangan likuiditas dan kapitalisasi pasar dengan kriteria-kriteria yang sudah 
ditentukan. Review dan pergantian emiten yang masuk dalam indeks ini dilakukan setiap enam bulan (idx.co.id).

\section{LITERATURE REVIEW}

The traditional society

\section{Teori Keagenan}

Jensen \& Meckling (1976) mendefisikan hubungan keagenan sebagai sebuah kontrak antara satu orang atau lebih pemilik (principal) yang menyewa orang lain (agent) untuk melakukan beberapa jasa atas nama pemilik yang meliputi pendelegasian wewenang pengambilan keputusan kepada agen. Principal adalah pemegang saham atau investor, sedangkan agent adalah manajemen yang mengelola perusahaan. Pemilik akan mendelegasikan tanggung jawab kepada manajemen, dan manajemen setuju untuk bertindak atas pemerintah atau wewenang yang diberikan pemilik.

\section{Good Corporate Governance}

Konsep corporate governance, berkaitan dengan bagaimana para principal memiliki keyakinan kepada agent dalam mengolah investasinya dan bertujuan memberikan nilai tambah bagi semua pihak berkepentingan (stakeholders). Daily dan Dalton (1993) mengemukakan bahwa corporate governance merupakan suatu tata kelola perusahaan yang didasarkan pada teori keagenan. Corporate governance diharapkan dapat mengatasi agency problems dengan memberi keyakinan kepada para pemegang saham bahwa mereka akan menerima return atas dana yang telah diinvestasikan.

\section{Kepemilikan Manajerial}

Jensen dan Meckling (1976) menyatakan bahwa untuk mengurangi konflik kepenting antara agent dan prinsipal dapat dilakukan dengan meningkatkan kepemilikan manajerial dalam suatu perusahaan. Manajer yang sekaligus pemegang saham akan meningkatkan nilai perusahaan, karena dengan meningkatnya nilai perusahaan maka nilai kekayaannya sebagai individu pemegang saham akan ikut meningkat pula (Soliha dan Taswan, 2002 dalam Christiawan dan Tarigan, 2007).

\section{Kepemilikan Institusional}

Pemegang saham institusional biasanya berbentuk entitas seperti perbankan, asuransi, dana pensiun, reksadana. Investor institusional memiliki kapabilitas untuk menganalisis laporan keuangan secara langsung dibandingkan investor individual. Potter (1991) menyatakan bahwa laporan keuangan periodik yang diterbitkan manajemen sebagai sumber informasi bagi investor institusional dalam melakukan aktivitas monitoring. Shleifer dan Vishny (1986) berpendapat bahwa kepemilikan institusional 
yang cukup besar akan mempengaruhi nilai pasar perusahaan. Semakin besar tingkat kepemilikan saham oleh institusi, maka semakin efektif mekanisme kontrol terhadap kinerja manajemen.

\section{Komisaris Independen}

Komisaris independen merupakan dewan komisaris yang berasal dari luar perusahaan (tidak memiliki hubungan afiliasi), dipilih secara transparan, sesuai dengan perundang-undangan yang berlaku, serta memiliki kemampuan yang memadai, salah satunya harus memiliki latar belakang bidang akuntansi dan keuangan. Permasalahan yang timbul dalam penerapan corporate governance apabila Chief Executive Officer (CEO) memiliki kekuatan lebih besar dibandingkan dewan komisaris padahal fungsi dewan komisaris adalah mengawasi kinerja dewan direksi yang dipimpin CEO tersebut. Efektivitas dewan komisaris dalam menyeimbangkan kekuatan CEO sangat dipengaruhi oleh tingkat independensi dari dewan komisaris (Lorsch, 1989; Mizruchi, 1983; Zahra \& Pearce, 1989 dalam Wardani, 2006).

\section{Komite Audit}

BAPEPAM melalui Surat Edaran No.SE-03/PM/2000 menghimbau perusahaan publik untuk membentuk komite audit. Anggota komite audit diangkat dari anggota dewan komisaris yang tidak melaksanakan tugas eksekutif dan terdiri paling sedikit tiga anggota yang independen. Komite audit mengadakan rapat tiga sampai empat kali setahun untuk melaksanakan kewajiban dan tanggungjawabnya. Komite audit memberi pendapat professional kepada dewan komisaris untuk meningkatkan kualitas kerja dan mengurangi penyimpangan pengelolaan perusahaan.

\section{Manajemen Laba}

Healy and Wahlen (1998) menyatakan bahwa manajemen laba mengandung beberapa aspek. Pertama, tujuan manajemen laba untuk menyesuaikan para investor mengenai kinerja perusahaan. Hal ini muncul ketika manajemen percaya bahwa investor tidak dapat mengungkap manajemen laba tersebut atau manajemen memiliki akses terhadap informasi yang tidak dapat diakses oleh pihak luar. Kedua, manajemen laba dapat dilakukan karena adanya investasi manajemen dalam menggunakan keputusan tertentu terhadap pelaporan keuangan. Misalnya keputusan untuk mengestimasikan sejumlah peristiwa ekonomi dimana yang akan datang ditunjukkan dalam laporan keuangan, seperti perkiraan umur ekonomis dan nilai residu aktiva tetap, pajak yang ditangguhkan dan penurunan nilai aset.

\section{Kinerja Keuangan}

Kinerja keuangan merefleksikan kinerja fundamental perusahaan. Kinerja keuangan diukur dengan data fundamental perusahaan, yaitu data yang berasal dari laporan keuangan (Ujiyantho dan Pramuka, 2007). Cash Flow Return On Asset (CFROA) merupakan salah satu pengukuran kinerja keuangan perusahaan yang menunjukkan 
kemampuan aktiva perusahaan untuk menghasilkan laba operasi. CFROA lebih memfokuskan pada pengukuran kinerja perusahaan saat ini dan CFROA tidak terikat dengan saham (Cornettt et.al, 2006). Informasi arus kas historis sering digunakan sebagai indikator dari jumlah, waktu, dan kepastian arus kas masa depan. Di samping itu, menurut PSAK No.2 informasi arus kas historis juga berguna untuk meneliti kecermatan dari taksiran arus kas masa depan yang telah dibuat sebelumnya dan dalam menentukan hubungan antara profiitabilitas dan arus kas bersih serta dampak perubahan harga.

\section{Previous Study and Hypothesis}

\section{Pengaruh Kepemilikan Manajerial terhadap Kinerja Keuangan}

Manajemen bertanggungjawab untuk menghasilkan laporan keuangan yang baik dan transparan sebagai bagian dari corporate governance. Tanpa adanya pengelolaan yang baik maka dapat terjebak ke dalam perilaku maupun proses yang condong pada segala cara untuk mencapai tujuan yang diinginkan. Saham yang dimiliki pihak manajer perusahaan, ikut menentukan kebijakan dan pengambilan keputusan terhadap metode akuntansi yang diterapkan pada perusahaan yang mereka kelola. Jensen dan Meckling (1976) membuktikan bahwa kepemilikan saham oleh manajer dapat mensejajarkan kepentingan antara manajer dan pemegang saham. Menurut Manik (2011) dan Halim (2013) kepemilikan manajerial berpengaruh terhadap kinerja keuangan. Berdasarkan uraian di atas, maka dapat dirumuskan hipotesis sebagai berikut :

$\mathrm{H}_{1}$ : Kepemilikan manajerial berpengaruh terhadap kinerja keuangan

\section{Pengaruh Kepemilikan Institusional terhadap Kinerja Keuangan}

Saham yang dimiliki pihak institusional dapat mempengaruhi dan mengendalikan pihak manajemen dalam proses penyusunan laporan keuangan. Menurut penelitian Widyawati (2013) kepemilikan institusional berpengaruh positif terhadap kinerja keuangan perusahaan. Cornett et al. (2006) membuktikan bahwa tindakan pengawasan yang dilakukan oleh sebuah perusahaan dan pihak investor institusional dapat membatasi perilaku manajer. Berdasarkan uraian di atas, maka dapat dirumuskan hipotesis sebagai berikut :

$\mathrm{H}_{2}$ : Kepemilikan institusional berpengaruh terhadap kinerja keuangan

\section{Pengaruh Komisaris Independen terhadap Kinerja Keuangan}

Komisaris independen adalah anggota dewan komisaris yang tidak terafiliasi dengan manajemen, anggota dewan komisaris lainnya, dan pemegang saham pengendali serta bebas dari hubungan bisnis atau hubungan lainnya yang dapat mempengaruhi kemampuannya untuk bertindak independen atau bertindak semata-mata demi kepentingan perusahaan (Komite Nasional Kebijakan Governance, 2006). Fama dan Jensen (1983) menyatakan bahwa kehadiran dewan komisaris independen berperan penting dalam pengambilan keputusan yang efektif. Menurut penelitian Manik (2011), 
Kumaat (2013), Halim (2013), komisaris independen berpengaruh terhadap kinerja keuangan. Berdasarkan uraian tersebut dapat dirumuskan hipotesa sebagai berikut:

$\mathrm{H}_{3}$ : Komisaris Independen berpengaruh terhadap kinerja keuangan

\section{Pengaruh Komite Audit terhadap Kinerja Keuangan}

Keberadaan komite audit diharapkan dapat meningkatkan kualitas laba. Semakin banyak jumlah komite audit yang dimiliki oleh suatu perusahaan maka akan memberikan perlindungan terhadap laporan keuangan melalui pengawasan dan kontrol yang lebih baik terhadap proses akuntansi dan akhirnya memberi pengaruh terhadap kinerja keuangan perusahaan. Menurut Manik (2011), Widaywati (2013) dan Halim (2013) komite audit berpengaruh terhadap kinerja keuangan. Berdasarkan uraian tersebut dapat dirumuskan hipotesa sebagai berikut:Berdasarkan uraian di atas, maka dapat dirumuskan hipotesis sebagai berikut :

$\mathrm{H}_{4}$ : Kepemilikan manajerial berpengaruh terhadap kinerja keuangan

\section{Pengaruh Manajemen Laba terhadap Kinerja Keuangan}

Manajemen laba merupakan salah satu faktor yang mempengaruhi kinerja perusahaan. Dalam hubungannya dengan kinerja, laporan keuangan sering dijadikan dasar untuk penilaian dasar kinerja perusahaan, Salah satu jenis laporan keuangan yang mengukur keberhasilan operasi perusahaan untuk suatu periode tertentu adalah laporan laba rugi. Akan tetapi angka laba yang dihasilkan dalam laporan laba rugi seringkali dipengaruhi oleh metode akuntansi yang digunakan oleh manajemen untuk mendapatkan laba yang sesuai dengan motivasinya.

Sehingga laba yang tinggi belum tentu mencerminkan kas yang besar. Hal ini akan mempengaruhi kualitas kinerja yang dilaporkan oleh manajemen. Investor cenderung overestimate terhadap persistensi akrual, serta underestimate persistensi arus kas. Di sisi lain, juga terdapat bukti empirik bahwa informasi akrual relevan untuk penilaian perusahaan (Dechow 1994, Subramanyam 1996).

Arus kas menunjukkan hasil operasi yang dananya telah diterima tunai oleh perusahaan serta dibebani dengan beban yang bersifat tunai dan benar-benar sudah dikeluarkan oleh perusahaan (Pradhono, 2004). Cash Flow Return On Assets (CFROA) merupakan salah satu pengukuran kinerja perusahaan yang menunjukkan kemampuan aktiva perusahaan untuk menghasilkan laba operasi. CFROA lebih memfokuskan pada pengukuran kinerja perusahaan saat ini dan CFROA tidak terikat dengan harga saham (Cornettt et.al, 2006). Berdasarkan uraian tersebut dapat dirumuskan hipotesa sebagai berikut

$\mathrm{H}_{5}$ : Manajemen Laba berpengaruh terhadap kinerja keuangan 


\section{RESEARCH METHODS}

Penelitian ini mengambil populasi perusahaan yang tercatat berturut-turut dalam indeks LQ 45 tahun 2013 di Bursa Efek Indonesia. Sample yang digunakan dalam penelitian ini berjumlah 43 perusahaan. Data yang digunakan dalam penelitian ini adalah data sekunder berupa data laporan keuangan dan tersedianya informasi secara lengkap selama periode pengamatan. Dipilih emiten yang tercatat dalam indeks LQ 45 karena indeks ini kelompok LQ 45 merupakan 45 saham terpilih yang memenuhi kriteria likuiditas, kapitali pasar yang tinggi, memiliki frekuensi perdagangan yang tinggi dan memiliki prospek pertumbuhan serta kondisi keuangan yang cukup baik. Dengan kriteria tersebut, kelompok LQ 45 merupakan kelompok perusahaan yang menjadi fokus perhatian investor.

Dalam penelitian ini, discretionary accruals sebagai proksi atas manajemen laba diukur dengan menggunakan Modified Jones Model, karena model ini mempunyai standard eror (eror term) hasil regresi estimasi nilai total actual yang paling kecil dibandingkan model-model yang lainnya dan dapat mendeteksi manajemen laba lebih baik jika dibandingkan dengan model-model yang lainnya, sejalan dengan hasil penelitian Dechow et al. (1995). Sedangkan CFROA dihitung dari laba sebelum bunga dan pajak ditambah depresiasi dibagi dengan total aset.

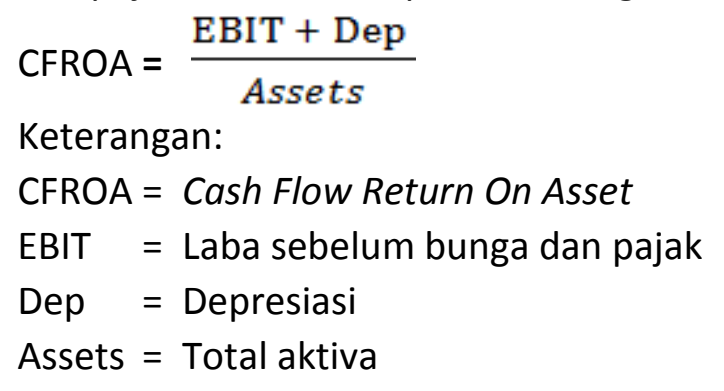

\section{RESULT AND ANALYSIS}

Tabel 1

Hasil Pengujian Analisis Regresi

\begin{tabular}{|l|r|c|}
\hline & $\begin{array}{c}\text { Unstandardized } \\
\text { Coefficients }\end{array}$ & Sig.t \\
\cline { 2 - 2 } & $\boldsymbol{\beta}$ & \\
\hline Konstanta & 0.005 & 0.980 \\
Kepemilikan Manajerial & -0.986 & 0.463 \\
Kepemilikan Institusional & 0.197 & 0.359 \\
Komisaris Independen & -0.134 & 0.663 \\
Komite Audit & 0.076 & 0.063 \\
Manajemen Laba & -0.031 & 0.006
\end{tabular}




\section{Kepemilikan Manajerial}

Kepemilikan manajerial tidak berpengaruh terhadap kinerja keuangan. Hasil penelitian ini sesuai dengan penelitian yang dilakukan Hanani dan Aryani (2011) dan Widayawati (2013) yang menyimpulkan bahwa kepemilikan manajerial tidak memiliki pengaruh terhadap kinerja keuangan perusahaan. Kepemilikan manajerial dari pihak direksi maupun komisaris proporsinya hanya sebagian kecil dari keseluruhan saham yang ada. Terdapat kemungkinan karena proporsi yang kepemilikan yang kecil manajemen belum merasakan manfaatnya dari kepemilikan tersebut sehingga manajemen tidak dapat melakukan tindakan untuk meningkatkan nilai saham yang dimilikinya melalui kinerja keuangan. Hasil penelitian ini tidak konsisten dengan penelitian terdahulu yang dilakukan oleh Manik (2011) yang menyatakan kepemilikan manajerial berpengaruh terhadap kinerja keuangan, sedangkan menurut Kumaat (2013) kepemilikan manajerial berpengaruh negatif terhadap kinerja keuangan.

\section{Kepemilikan Institusional}

Kepemilikan institusional tidak berpengaruh terhadap kinerja keuangan. Hasil penelitian ini sejalan dengan penelitian yang dilakukan Manik (2011) yang menyatakan kepemilikan institusional tidak berpengaruh terhadap kinerja keuangan. Hasil tidak signifikan ini dapat dimungkinkan karena para investor institusional cenderung melihat komposisi pemegang saham dengan kurang efektif. Adanya pemegang saham utama menyebabkan terdapat kemungkinan pengambilan keputusan tidak dilakukan secara obyektif, melainkan berdasarkan pendapat pemegang saham mayoritas. Investor institusional cenderung menilai bahwa pengambilan keputusan dalam perusahaan akan sangat dipengaruhi oleh pemegang saham mayoritas yang ikut dalam pengendalian perusahaan sehingga cenderung bertindak untuk kepentingan mereka sendiri meskipun dengan mengorbankan kepentingan pemilik minoritas. Selama perusahaan menghasilkan keuntungan, investor institusional akan tetap memegang sahamnya tapi tidak dapat mempengaruhi kinerja perusahaan. Hasil penelitian ini bertentangan dengan Cornett et.al (2006) dan Widayawati (2013) yang menyatakan bahwa kepemilikan institusional berpengaruh terhadap kinerja perusahaan.

\section{Komisaris Independen}

Kepemilikan institusional tidak berpengaruh terhadap kinerja keuangan. Hasil penelitian ini mengkonfrimasi penelitian Ponnu (2008) dan Romano (2012) yang menyimpulkan bahwa komisaris independen tidak berpengaruh terhadap kinerja keuangan. Hasil penelitian ini menunjukkan bahwa independensi komisaris tidak memberikan kontribusi terhadap peningkatan kinerja keuangan. Tingginya proporsi komisaris independen menandakan banyaknya komisaris yang berasal dari luar perusahaan. Semakin banyak komisaris yang berasal dari luar perusahaan mengakibatkan pengetahuan para anggota dewan komisaris mengenai masalah dan 
kondisi perusahaan secara mendetail semakin sedikit. Akibatnya dalam menjalankan perusahaan, peran dewan komisaris tidak menjadi maksimal. Menurut Darwis (2009) keberadaan komisaris independen dalam perusahaan hanyalah bersifat formalitas untuk memenuhi regulasi saja. Oleh karena itu, meskipun tingkat independensi dalam dewan komisaris sudah tinggi, tetap saja tidak akan mempengaruhi kinerja keuangan perusahaan agar semakin baik, tetapi malah justru sebaliknya. Hasil penelitian ini bertentangan dengan Manik (2011) dan Widayawati (2013) yang menyatakan bahwa komisaris independen berpengaruh terhadap kinerja keuangan.

\section{Komite Audit}

Komite audit tidak berpengaruh terhadap kinerja keuangan. Hasil ini sejalan dengan Romano (2012) dan Widayawati (2013) yang menyatakan bahwa jumlah komite audit tidak berpengaruh terhadap kinerja keuangan. Hal ini menunjukkan jumlah komite audit tidak menjamin kinerja komite audit berjalan dengan efektif dalam melakukan tugasnya yaitu pengawasan terhadap kinerja keuangan. Keberadaan komite audit sebagai salah satu mekanisme corporate governance tidak mempengaruhi kinerja keuangan kemungkinan disebabkan keberadaannya hanya untuk memenuhi ketentuan peraturan serta sebagian besar kurang memiliki latarbelakang akuntansi dan keuangan. Hasil penelitian ini bertentangan dengan Cornett et.al (2006) dan Manik (2011) yang menyatakan komite audit berpengaruh terhadap kinerja keuangan.

\section{Manajemen Laba}

Manajemen laba berpengaruh terhadap kinerja keuangan. Hasil ini sejalan dengan Cornett et.al (2006) yang menemukan adanya pengaruh penurunan discretionary accruals sebagai ukuran dan dari manajemen laba dan berhubungan positif dengan kinerja keuangan, Halim (2013) serta Anggit dan Shodiq (2014) yang menyimpulkan manajemen laba berpengaruh terhadap kinerja keuangan. Tujuan manajemen laba adalah mengatur laporan keuangan agar sesuai dengan apa yang diinginkan manajer berdasarkan kepentingannya. Semakin tinggi manajemen laba yang dilakukan maka kinerja keuangan akan semakin terlihat baik terutama berkaitan dengan memperbaiki laporan yang berbeda dengan kondisi perusahaan yang sebenarnya. Hasil penelitian ini berbeda dengan Ujiyantho dan Pramuka (2007) yang menyatakan variabel discretionary accruals tidak berpengaruh signifikan terhadap cash flow return on assets.

\section{CONCLUSION}

Kesimpulan dari penelitian ini yaitu epemilikan manajerial, kepemilikan institusional, komisaris independen, dan komite audit tidak berpengaruh terhadap kinerja keuangan. Manajemen laba berpengaruh signifikan terhadap kinerja keuangan. Berdasarkan keterbatasan yang terdapat pada penelitian ini, maka saran bagi penelitian 
selanjutnya adalah dapat melakukan perbandingan antar indeks saham di Bursa Efek Indonesia dengan penggunaan model yang sama sehingga memberikan variasi dalam pengujian konsistensi model yang ada. Penggunaan model yang berbeda dalam menentukan corporate governance maupun discretionary accrual serta memperpanjang periode pengamatan sehingga dapat melihat adanya mekanisme tata kelola perusahaan dan manajemen laba dengan sudut pandang yang berbeda.

\section{REFERENCES}

Alves, Sandra. 2012. Ownership Structure and Earnings Management: Evidence from Portugal. Australasian Accounting Business and Finance Journal. 6(1):57-74.

Ardekani, Aref Mahdavi., Younesi, Nejat., Hashemijoo, Mohammad. 2012. Acquisition, Earnings Management and Firm's Performance: Evidence from Malaysia. Journal of Business Studies Quarterly. Vol. 4, No. 1:. 91-110.

Anggit, Domas Titis., Shodiq, Muhammad Ja'Far. 2014. Hubungan Antara Mekanisme Corporate Governance, Manajemen Laba dan Kinerja Keuangan (Studi Empiris pada Perusahaan Manufaktur di BEI Tahun 2008-2010). Simposium Nasional Akuntansi 17 Mataram.

Chen, KY., Elder, RJ \& Hsieh, Y-M. 2007. Corporate governance and earnings management: The Implications of Corporate Governance Best-Practice Principles for Taiwanese Listed Companies. Journal of Contemporary Accounting \& Economics. Vol.3, No.2:73-105.

Christiawan, Yulius Jogi dan Tarigan Josua. 2007. Kepemilikan Manajeral: Kebijakan Hutang, Kinerja dan Nilai Perusahaan. Jurnal Akuntansi dan Keuangan. Vol. 9, No. 1, Mei: 1-8.

Cornett, M.M., A.J. Marcus., A, Saunders \& H. Tehranian. 2006. Earnings Management,Corporate Governance, and True Financial Performance. http://papers.ssrn.com

Daily, Catherine M., dan R. Dalton. 1993. Bankruptcy and Corporate Governance: The Impact of Board Composition and Structure. The Academy of Management Journal. Vol. 37(6), December :1603-1617.

Dechow, P.M. 1994. Accounting Earning and Cash Flows as Measures of Firm Performance: The Role of Accounting Accruals. Journal of Accounting and Economics. No.18: 3-42.

Dechow, Patricia.M., Sloan, R.G., Sweney, A.P. 1995. Detecting Earning Management. The Accounting Review. Vol. 70 No.2, April: 93-225.

Dechow, P.M. and Dichev, I.D. 2002. The Quality of Accruals and Earnings: The Role of Accruals Estimation Errors. The Accounting Review. Vol. 77: 35-59.

DeFond, ML \& Jiambalvo, J . 1994. Debt covenant violation and manipulations of accruals. Journal of Accounting and Economics. Vol.17: 145-176.

Fama, Eugene F. and Jensen, M.C. 1983. Separation of Ownership and Control. Journal of Law and Economics. Vol. XXVI: 301-326. 
Gunny, K. 2005. What are the Consequences of real Earnings Management?.www.papers.ssrn.com.

Halim, Kusuma Indawati. 2013. Kajian Atas Good Corporate Governance dan Earnings Management terhadap Kinerja Perusahaan. Jurnal Socioscientia. Vol.5, No. 2, Juni.

Hanani, Famera dan Aryani, Y. Anni. 2011. Pengaruh Gender Dewan Komisaris, Gender Dewan Direksi, dan Kepemilikan Manajerial Terhadap Kinerja Keuangan. Wahana. Vol. 4, No. 1, Februari.

Healy, P.M. 1985. The Impact of Bonus Schemes on the Selection of Accounting Principles. Journal of Accounting and Economics, 7:85-107.

Healy, P.M. dan James M. Wahlen. 1999. A Review of The Earnings Management Literature and Its Implications for Standard Setting. Accounting Horizon, 13: 365383, December.

Ikatan Akuntan Indonesia. 2007. Standar Akuntansi Keuangan. Jakarta: Salemba Empat.

Jensen, Michael C. dan William H. Meckling. 1976. Theory Of The Firm: Managerial Behavior, Agency Costs And Ownership Structure. Journal of Financial Economics. Vol. 3, No. 4: 305-360.

Jones. J. J. 1991. Earnings Management During Import Relief Investigations. Journal of Accounting Research 29 (2): 193-228.

Komite Nasional Kebijakan Governance (KNKG). 2006. Pedoman Umum Good Corporate Governance Indonesia. Jakarta.

Kumaat, Lusye Corvanty. 2013. Corporate Governance dan Struktur Kepemilikan Terhadap Manajemen Laba dan Kinerja Keuangan. Jurnal Keuangan dan Perbankan. Vol.17, No.1:11-20, Januari.

Manik, Tumpal. 2011. Analisis Pengaruh Kepemilikan Manajemen, Komisaris Independen, Komite Audit, Umur Perusahaan Terhadap Kinerja Keuangan (Studi Empiris Perusahaan Property \& Real Estate di BEI). JEMI. Vol.2, No.2, Desember.

Martsila, Ika Surya dan Meiranto, Wahyu. 2013. Pengaruh Corporate Governance Terhadap Kinerja Keuangan Perusahaan. Diponegoro Journal of Accounting. Vol.2, No.4.

Nuryaman. 2013. The Influence of Earnings Management on Stock Return and the Role of Audit Quality as a Moderating Variable. International Journal of Trade, Economics and Finance. Vol. 4, No. 2, April.

Peasnell, KV, Pope, PF \& Young, S 2000, Accrual Management to Meet Earnings Targets: UK Evidence Pre-and Post-Cadbury. British Accounting Review. Vol.32: 415-445.

Potter, G. 1991. Accounting Earnings Announcement, Institutional Investors Concentration and Common Stock Returns. Journal of Accounting Research, Vol.30. No. 1. p.146-155.

Pradhono dan Yulius Jogi Crhristiawan. 2004. Pengaruh Economic Value Added, Residual Income, Earnings dan Arus Kas Operasi Terhadap Return yang Diterima Oleh Pemegang Saham (Studi pada Perusahaan Manufaktur yang Terdaftar di Bursa Efek Jakarta). Jurnal Akuntansi dan Keuangan. Vol.6: 140-166, November. 
Subramanyam, K. R. 1996. The Pricing of Discretionary Accruals. Journal of Accounting and Economics. No.22: 249-281.

Ujiyantho, Muh. Arief dan Bambang Agus Pramuka. 2007. Mekanisme Corporate Governance, Manajemen Laba dan Kinerja Keuangan (Studi Pada Perusahaan go publik Sektor Manufaktur). Simposium Nasional Akuntansi 10 Makassar.

Wardani, Ratna. 2006. Mekanisme Corporate Governance Dalam Perusahaan Yang Mengalami Permasalahan Keuangan(Financially Distressed Firms). Simposium Nasional Akuntansi XI, Padang.

Yang, C-Y, Lai, H-N \& Tan, BL. 2008. Managerial Ownership Structure and Earnings Management. Journal of Financial Reporting \& Accounting. Vol.6, No. 1:35-53. 